\title{
Prevention of cisplatin-based chemotherapy-induced delayed nausea and vomiting using triple antiemetic regimens: a mixed treatment comparison
}

\author{
Qi Shi ${ }^{1, *}$, Wen Li ${ }^{1, *}$, Hongjia Li ${ }^{1}$, Qiqi Le ${ }^{3}$, Shanshan Liu ${ }^{1}$, Shaoqi Zong ${ }^{1}$, Leizhen Zheng ${ }^{2}$, \\ Fenggang Hou ${ }^{1}$ \\ ${ }^{1}$ Oncology Department of Municipal Hospital of Traditional Chinese Medicine, Shanghai University of Traditional Chinese \\ Medicine, Shanghai 200071, China \\ ${ }^{2}$ Oncology Department of Xin Hua Hospital Affiliated To Shanghai Jiaotong University School of Medicine, Shanghai, 200092, \\ China \\ ${ }^{3}$ Digestive Department of Municipal Hospital of Traditional Chinese Medicine, Shanghai University of Traditional Chinese \\ Medicine, Shanghai 200071, China \\ *These authors contributed equally to this work \\ Correspondence to: Fenggang Hou, e-mail: fghou555@126.com \\ Leizhen Zheng, e-mail: zhengleizhen2006@126.com
}

Keywords: chemotherapy-induced nausea and vomiting (CINV), highly emetogenic chemotherapy, cisplatin-based chemotherapy

Received: November 28, 2015

Accepted: February 24, 2016

Published: March 22, 2016

\section{ABSTRACT}

A variety of triple antiemetic regimens are being used to prevent cisplatin-based chemotherapy induced delayed emesis and nausea in cancer patients. We performed a network meta-analysis to compare the efficacies of the different regimens. Electronic searches of the PubMed, Cochrane Library and MEDLINE databases were performed to identify randomized controlled trials, and data were analyzed using JAGS, Stata 14.0 and $\mathbf{R}$ project. The primary outcome was a complete response (CR). The secondary outcomes were no vomiting (NV) and no nausea (NN). Among the 398 studies identified, 10 were eligible and included, providing data on nine regimens. In the CR analysis, the absolute rank of netupitant + palonosetron + dexamethasone (NEPA) was 0.8579. In the NV and NN analyses, NEPA's absolute ranks were 0.8631 and 0.7902 , respectively. The compliance of patients treated with rolapitant + granisetron + dexamethasone (RGD) was the best due to a low incidence of adverse events, and good compliance was also observed with NEPA. It was difficult to achieve good compliance with aprepitant + granisetron + dexamethasone (AGD). Overall, NEPA was the best regimen, and aprepitant + ondansetron + dexamethasone (AOD) is also worthy of recommendation because of its low cost and good effect. For patients with severe constipation, hiccups, asthenia and/or delayed nausea, RGD is worthy of consideration.

\section{INTRODUCTION}

Chemotherapy-induced nausea and vomiting (CINV) is a common adverse event in the treatment of cancer and constitutes the main reason for patients' refusal of chemotherapy $[1,2]$. In recent years, although more than $90 \%$ of highly emetogenic chemotherapy (HEC)-induced acute vomiting has been effectively controlled using neurokinin-1 (NK-1) and serotonin (5-HT3) antagonists
[3-5], 25-35\% of delayed vomiting and $60-70 \%$ of delayed nausea remain difficult to control [6-9]. The National Comprehensive Cancer Network (NCCN) guidelines for antiemesis (2015.V1) recommend a triple regimen of a NK-1 and 5-HT3 antagonist plus dexamethasone (DXM) to control delayed nausea and vomiting. However, the various regimens in use have never been directly compared, and this lack of information makes it difficult for clinicians to select the optimal antiemetic triple regimen. 
Cisplatin, which is widely used in cancer chemotherapy, commonly causes delayed nausea and vomiting $[10,11]$. To identify a better triple regimen for cisplatin-based chemotherapy-induced delayed nausea and vomiting, we performed a network meta-analysis of published clinical trials whose outcomes included a complete response (CR), no vomiting (NV), no nausea $(\mathrm{NN})$, and the effects of triple regimens on chemotherapy-related adverse events.

\section{RESULTS}

\section{Literature search and study characteristics}

A total of 393 citations and 5 additional records were identified in the electronic database search (Figure 1). Of those, 270 potentially relevant articles were retrieved and assessed in greater detail. From that group, 128 studies were excluded because they did not involve randomized controlled trials (RCTs). Also excluded were 88 studies not related to cisplatin-based chemotherapy, 41 that presented uncorrelated outcomes, and 3 that did not include triple therapy. Ultimately, 10 studies [12-21] fulfilled the eligibility criteria (Table 1). The Jadad scores (Supplementary Table S1) of all of the included studies were calculated to be $4-5$, indicating that they were of high quality.

\section{Risk of bias}

The methodological quality of the included studies was generally good. Across all six domains, approximately $71.6 \%$ of the assessments were classified as 'low risk', and $1.7 \%$ were classified as 'high risk'. It is unlikely that the evidence presented in this review was affected by biases associated with performance. However, we cannot exclude the possibility that selection bias was present in some individual trials, since they lacked a description of their allocation. In addition, some uncertainty regarding the risks of bias associated with random sequence generation and with the blinding of outcome assessors was due mainly to insufficient reporting. The risk of bias in the included studies is summarized in Supplementary Figures S1-S2.

\section{Traditional meta-analysis}

We performed a series of pairwise meta-analyses to evaluate antiemetic regimens. Figure 2 shows that most of the comparisons did not reveal significant differences for $\mathrm{CR}$ and NV, though the ORs were significantly better with aprepitant + ondansetron + dexamethasone (AOD) than with ondansetron + dexamethasone (OD), and were better with aprepitant + granisetron + dexamethasone (AGD) than with granisetron + dexamethasone (GD). In addition, we found that the $l^{2}$ values were $>50 \%$ for analyses of CR and NV, indicating acceptable levels of heterogeneity. For analysis of NN, however, the ORs were significantly better for AOD than for OD and for rolapitant + ondansetron + dexamethasone (RGD) than for GD. In addition, no significant heterogeneity was detected, with an $I^{2}$ value of $>50 \%$.

Because heterogeneity was detected in the CR and $\mathrm{NV}$ analyses, we conducted sensitivity analyses to verify the stability of the results. As shown in Figure 2, the small-sample study had no substantial impact on the results. However, the study by Grunberg et al. [20] had the greatest effect on the combined results (Supplementary Figure S3). We suggest the heterogeneity detected may have been due to the significantly larger sample size in this study than in the other studies.

\section{Network meta-analysis (combination of direct and indirect comparisons)}

We used a fixed effects model to analyze the data because it provides a narrower interval estimation. Table 2 shows an evaluation of consistency in CR. Each partition node shows the differences between the direct and indirect results. The corresponding $P$ values are $>0.05$; there is thus no evidence that the network model is inconsistent.

Figure 3 shows the network structures for CR, $\mathrm{NV}$ and NN. Each solid line links treatments directly compared within a trial, while each dotted line indicates a lack of direct comparison between treatments. The thicknesses of the solid lines are proportional to the number of comparisons included in the network, and the diameters of the circles are proportional to the number of studies involving the specific treatments.

\section{Efficacy endpoint}

\section{Complete response (CR)}

Figure 4 shows the preventive effect of 8 antiemetic regimens on delayed vomiting, with the outcomes of a total of 6,143 patients being reported. CR analysis revealed that netupitant + palonosetron + dexamethasone (NEPA) was the most effective treatment, with an absolute rank of 0.8579 The ranking from high to low was as follows: AOD, fosaprepitant + ondansetron + dexamethasone (FOD), palonosetron + dexamethasone (PD), AGD, RGD, fosaprepitant + granisetron + dexamethasone (FGD), GD and OD. However, the results should be interpreted with caution because most of comparisons among the various regimens did not reach statistical significance.

\section{No vomiting (NV)}

The results of the NV analysis are shown in Figure 5. In nine studies, a total of nine antiemetic regimens and 4,835 patients were analyzed. The absolute rank of NEPA was 0.8631, which indicates this regimen 
may be optimal. The emetic regimens in decreasing order of absolute rank were as follows: AOD, FOD, AGD, PD, FGD, RGD, OD and GD. Again, these findings should be interpreted with caution because most of the comparisons did not reach statistical significance.

\section{No nausea (NN)}

The results of the NN analysis are shown in Figure 6. In seven studies, a total of eight antiemetic regimens and 3,409 patients were analyzed. The FOD regimen was not analyzed in this section because the studies in which it was included did not report the relevant data. The efficacy of NEPA was again the best, with an absolute rank of 0.7902 . In decreasing order, the ranking was as follows: PD, AOD, RGD, OD, AGD, FGD, and GD. These results should also be interpreted with caution.

\section{Safety}

The incidence of adverse events among the patients receiving the different triple antiemetic regimens are shown in Table 3. The incidences of constipation (23.9\%), anorexia (36.3\%) and hiccups $(35.5 \%)$ were the highest in the patients treated with AGD, while the incidence of asthenia $(14.3 \%)$ was the highest in the patients treated with AOD. The incidence of adverse events (constipation: $0.4 \%$, hiccups: $0.6 \%$ and asthenia: $0.4 \%$ ) was the lowest in patients treated with RGD.

\section{DISCUSSION}

In recent years, the prevention of CINV has been greatly improved by the widespread utilization of 5-HT3 and NK-1 antagonists. Although drugs in the same categories are unlikely to have different antiemetic properties, studies of triple regimens aimed at treating delayed nausea and vomiting have nonetheless received significant attention. The current evidence indicates that the efficacy of triple regimens is generally better than that of double regimens because of the interaction between NK-1 and 5-HT3 receptor antagonists [22-27]. However,

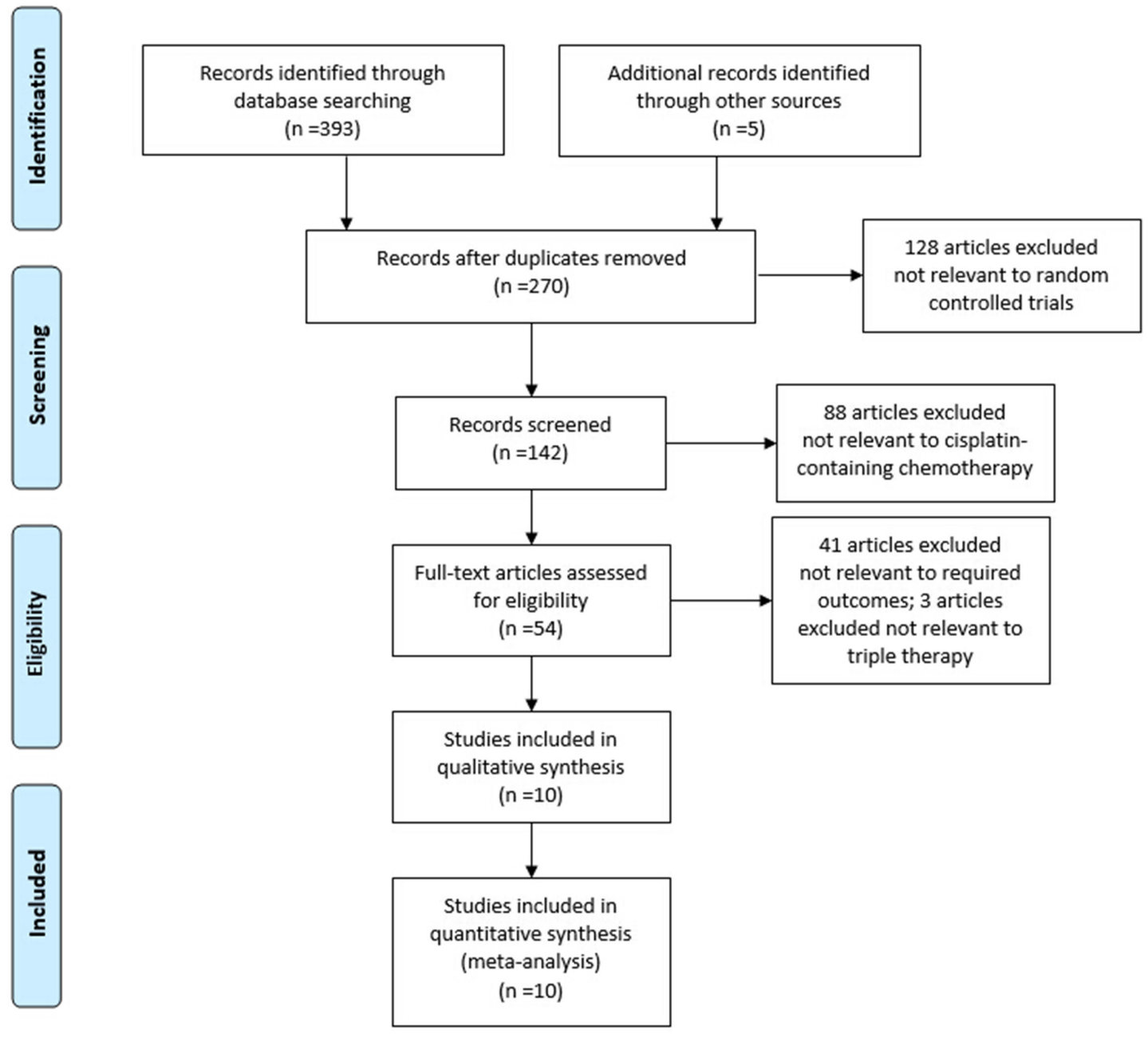

Figure 1: Summary of the identification and selection of clinical trials. 
Table 1: Main characteristics of the studies included in the meta-analysis

\begin{tabular}{|c|c|c|c|c|c|c|c|}
\hline \multirow[t]{2}{*}{ Study } & \multirow[t]{2}{*}{ Trial design } & \multirow[t]{2}{*}{ Patients } & \multicolumn{2}{|c|}{ Intervention } & \multirow[t]{2}{*}{ NV } & \multirow[t]{2}{*}{$\mathbf{N N}$} & \multirow[t]{2}{*}{ CR } \\
\hline & & & Acute phase & Delayed phase & & & \\
\hline $\begin{array}{l}\text { Paul J. } \\
\text { Hesketh, et al. } \\
2003[12]\end{array}$ & $\begin{array}{l}\text { parallelgroup } \\
\text { double-blind }\end{array}$ & 520 & $\begin{array}{c}\text { OND } 32 \mathrm{mg} \text { iv + DXM } 20 \mathrm{mg} \text { po } \\
\text { APR } 125 \mathrm{mg} \text { po + OND } 32 \mathrm{mg} \text { iv }+ \\
\text { DXM } 12 \mathrm{mg} \text { po }\end{array}$ & $\begin{array}{c}\text { DXM } 8 \text { mg po bid } \\
\text { APR } 80 \text { mg po }+ \text { DXM } 8 \\
\text { mg po on day } 2-3, \text { DXM } 8 \\
\text { mg on day } 4\end{array}$ & $\begin{array}{l}153 / 260 \\
(58.9 \%) \\
210 / 260 \\
(80.8 \%)\end{array}$ & $\begin{array}{l}124 / 260 \\
(47.7 \%) \\
133 / 260 \\
(51.2 \%)\end{array}$ & $\begin{array}{l}145 / 260 \\
(55.8 \%) \\
196 / 260 \\
(75.4 \%)\end{array}$ \\
\hline $\begin{array}{l}\text { Sant P. } \\
\text { Chawla, et al. } \\
2001[13]\end{array}$ & $\begin{array}{l}\text { parallelgroup } \\
\text { double-blind }\end{array}$ & 258 & $\begin{array}{c}\text { APR } 125 \mathrm{mg}+\text { OND } 32 \mathrm{mg} \text { iv }+ \\
\text { DXM } 20 \mathrm{mg} \text { po } \\
\text { Placebo po + OND } 32 \mathrm{mg}+ \\
\text { DXM } 20 \mathrm{mg}\end{array}$ & $\begin{array}{l}\text { APR } 80 \mathrm{mg}+\text { DXM } 8 \mathrm{mg} \\
\text { Placebo po + DXM } 8 \mathrm{mg}\end{array}$ & $\begin{array}{c}102 / 132 \\
(77.3 \%) \\
63 / 126 \\
(50.0 \%)\end{array}$ & $\begin{array}{c}77 / 132 \\
(58.3 \%) \\
46 / 126 \\
(36.5 \%)\end{array}$ & $\begin{array}{c}96 / 132 \\
(72.7 \%) \\
57 / 126 \\
(45.2 \%)\end{array}$ \\
\hline $\begin{array}{l}\text { Daniel } \\
\text { Campos, et al. } \\
2001[14]\end{array}$ & $\begin{array}{l}\text { parallelgroup } \\
\text { double-blind }\end{array}$ & 174 & $\begin{array}{c}\text { GRA } 10 \mu \mathrm{g} / \mathrm{kg} \text { iv + DXM } 20 \mathrm{mg} \text { po } \\
\text { GRA } 10 \mu \mathrm{g} / \mathrm{kg}+\text { DXM } 20 \mathrm{mg} \text { po }+ \\
\text { APR } 400 \mathrm{mg} \text { po }\end{array}$ & $\begin{array}{c}\text { Placebo po } \\
\text { APR } 300 \text { mg po }\end{array}$ & $\begin{array}{c}26 / 90 \\
(28.9 \%) \\
53 / 84 \\
(63.1 \%)\end{array}$ & N/A & N/A \\
\hline $\begin{array}{l}\text { Sergio } \\
\text { Poli-Bigelli, } \\
\text { et al. } 2003 \\
{[15]}\end{array}$ & $\begin{array}{l}\text { parallelgroup } \\
\text { double-blind }\end{array}$ & 523 & $\begin{array}{c}\text { OND } 32 \mathrm{mg} \text { iv + DXM } 20 \mathrm{mg} \text { po } \\
\text { APR } 125 \mathrm{mg} \text { po + OND } 32 \mathrm{mg} \text { po } \\
\text { + DXM } 12 \mathrm{mg} \text { po }\end{array}$ & $\begin{array}{c}\text { DXM } 8 \text { mg po bid } \\
\text { APR } 80 \text { mg po }+ \text { DXM } 8 \\
\text { mg po on day } 2-3, \text { DXM } 8 \\
\text { mg on day } 4\end{array}$ & $\begin{array}{l}126 / 263 \\
(47.9 \%) \\
187 / 260 \\
(71.9 \%)\end{array}$ & $\begin{array}{l}105 / 263 \\
(39.9 \%) \\
138 / 260 \\
(53.1 \%)\end{array}$ & $\begin{array}{l}123 / 263 \\
(46.8 \%) \\
176 / 260 \\
(67.7 \%)\end{array}$ \\
\hline $\begin{array}{l}\text { P. J. Hesketh, } \\
\text { et al. } \\
2014[16]\end{array}$ & $\begin{array}{l}\text { parallelgroup } \\
\text { double-blind }\end{array}$ & 403 & $\begin{array}{c}\text { PAL } 0.5 \mathrm{mg} \text { po + DXM } 20 \mathrm{mg} \text { po } \\
\text { + placebo } \\
\text { NETU } 300 \mathrm{mg} \text { po + PAL } 0.5 \mathrm{mg} \text { po } \\
\text { + DXM } 12 \mathrm{mg} \text { po } \\
\text { APR } 125 \mathrm{mg} \text { po + OND } 32 \mathrm{mg} \text { po } \\
\text { + DXM } 12 \mathrm{mg} \text { po APR }\end{array}$ & $\begin{array}{c}\text { DXM } 8 \text { mg po bid } \\
\text { DXM } 4 \text { mg po bid } \\
\text { APR } 80 \text { mg po }+ \text { DXM } 8 \\
\text { mg po on day } 2-3, \text { DXM } 8 \\
\text { mg on day } 4\end{array}$ & $\begin{array}{l}109 / 136 \\
(80.1 \%) \\
124 / 135 \\
(91.9 \%) \\
118 / 132 \\
(89.4 \%)\end{array}$ & $\begin{array}{l}110 / 136 \\
(80.9 \%) \\
122 / 135 \\
(90.4 \%) \\
116 / 132 \\
(87.9 \%)\end{array}$ & $\begin{array}{l}109 / 136 \\
(80.1 \%) \\
122 / 135 \\
(90.4 \%) \\
119 / 132 \\
(90.2 \%)\end{array}$ \\
\hline $\begin{array}{l}\text { H. Saito, et al. } \\
2013 \text { [17] }\end{array}$ & $\begin{array}{l}\text { parallelgroup } \\
\text { double-blind }\end{array}$ & 340 & $\begin{array}{c}\text { FOS } 150 \mathrm{mg} \text { iv }+ \text { GRA } 40 \mu \mathrm{g} / \mathrm{kg} \text { iv } \\
+ \text { DXM } 10 \mathrm{mg} \text { iv } \\
\text { Placebo iv + GRA } 40 \mu \mathrm{g} / \mathrm{kg} \text { iv }+ \\
\text { DXM } 20 \mathrm{mg} \text { iv }\end{array}$ & $\begin{array}{c}\text { DXM } 4 \mathrm{mg} \text { iv on day } 2 \text {, and } \\
8 \mathrm{mg} \text { on day } 3 \\
\text { DXM } 8 \mathrm{mg} \text { iv on day } 2-3\end{array}$ & $\begin{array}{c}119 / 173 \\
(68.8 \%) \\
85 / 167 \\
(50.9 \%)\end{array}$ & $\begin{array}{c}53 / 173 \\
(30.6 \%) \\
41 / 167 \\
(24.6 \%)\end{array}$ & $\begin{array}{c}112 / 173 \\
(64.7 \%) \\
81 / 167 \\
(48.5 \%)\end{array}$ \\
\hline $\begin{array}{l}\text { Toshiaki } \\
\text { Takahashi, } \\
\text { et al. } 2010 \\
{[18]}\end{array}$ & $\begin{array}{l}\text { parallelgroup } \\
\text { double-blind }\end{array}$ & 295 & $\begin{array}{c}\text { APR } 125 \mathrm{mg} \text { po }+ \text { GRA } 40 \mu \mathrm{g} / \mathrm{kg} \\
\text { iv }+ \text { DXM } 6 \mathrm{mg} \text { iv } \\
\text { Placebo po + GRA } 40 \mu \mathrm{g} / \mathrm{kg} \text { iv }+ \\
\text { DXM } 12 \mathrm{mg} \text { iv }\end{array}$ & $\begin{array}{c}\text { APR } 80 \mathrm{mg}+\text { DXM } 4 \mathrm{mg} \\
\text { on day } 2-3 \text {, and APR } 80 \\
\text { mg po on day 4-5 } \\
\text { Placebo po + DXM } 8 \text { mg iv } \\
\text { on day } 2-3 \text {, and placebo po } \\
\text { on day 4-5 }\end{array}$ & $\begin{array}{c}115 / 146 \\
(78.8 \%) \\
79 / 149 \\
(53.0 \%)\end{array}$ & $\begin{array}{c}51 / 146 \\
(34.9 \%) \\
39 / 149 \\
(26.2 \%)\end{array}$ & $\begin{array}{c}106 / 146 \\
(72.6 \%) \\
77 / 149 \\
(51.7 \%)\end{array}$ \\
\hline $\begin{array}{l}\text { Zhihuang } \mathrm{Hu} \text {, } \\
\text { et al. } \\
2014 \text { [19] }\end{array}$ & $\begin{array}{l}\text { parallelgroup } \\
\text { double-blind }\end{array}$ & 412 & $\begin{array}{c}\text { APR } 125 \mathrm{mg} \text { po + GRA } 3 \mathrm{mg} \text { iv }+ \\
\text { DXM } 6 \mathrm{mg} \text { po } \\
\text { Placebo po + GRA } 3 \mathrm{mg} \text { iv }+ \\
\text { DXM } 10.5 \mathrm{mg} \text { po }\end{array}$ & $\begin{array}{c}\text { APR } 80 \mathrm{mg} \text { po }+ \text { DXM } \\
3.75 \mathrm{mg} \text { po on day } 2-3 \text {, } \\
\text { DXM } 3.75 \mathrm{mg} \text { po on day } 4 . \\
\text { Placebo po }+ \text { DXM } 7.5 \mathrm{mg} \\
\text { po on day } 2-3 \text {, DXM } 7.5 \\
\text { mg po on day } 4 .\end{array}$ & N/A & N/A & $\begin{array}{l}151 / 204 \\
(74.0 \%) \\
124 / 208 \\
(59.6 \%)\end{array}$ \\
\hline $\begin{array}{l}\text { Steven } \\
\text { Grunberg, } \\
\text { et al. } 2011 \\
{[20]}\end{array}$ & $\begin{array}{l}\text { parallelgroup } \\
\text { double-blind }\end{array}$ & 2322 & $\begin{array}{l}\text { FOS } 150 \mathrm{mg} \text { iv }+ \text { OND } 32 \mathrm{mg} \text { iv }+ \\
\text { DXM } 12 \mathrm{mg} \text { po } \\
\text { APR } 125 \mathrm{mg} \text { po }+ \text { OND } 32 \mathrm{mg} \text { iv }+ \\
\text { DXM } 12 \mathrm{mg} \text { po }\end{array}$ & $\begin{array}{c}\text { DXM } 8 \mathrm{mg} \text { po on day } 2,8 \\
\text { mg po bid on day } 3-4 \\
\text { APR } 80 \mathrm{mg} \text { po }+ \text { DXM } 8 \\
\text { mg po on day } 3, \text { DXM } 8 \\
\text { mg po on day } 4\end{array}$ & $\begin{array}{c}867 / 1147 \\
(75.6 \%) \\
898 / 1175 \\
(76.4 \%)\end{array}$ & N/A & $\begin{array}{c}852 / 1147 \\
(74.3 \%) \\
872 / 1175 \\
(74.2 \%)\end{array}$ \\
\hline $\begin{array}{l}\text { Bernardo L } \\
\text { Rapoport, } \\
\text { et al. } 2015 \\
{[21]}\end{array}$ & $\begin{array}{l}\text { parallelgroup } \\
\text { double-blind }\end{array}$ & 1070 & $\begin{array}{c}\text { ROL } 180 \mathrm{mg} \text { po + GRA } 10 \mu \mathrm{g} / \mathrm{kg} \\
\text { iv + DXM } 20 \mathrm{mg} \text { po } \\
\text { GRA } 10 \mu \mathrm{g} / \mathrm{kg} \text { iv + DXM } 20 \mathrm{mg} \text { po }\end{array}$ & $\begin{array}{l}\text { DXM } 8 \mathrm{mg} \text { po bid } \\
\text { DXM } 8 \mathrm{mg} \text { po bid }\end{array}$ & $\begin{array}{l}404 / 535 \\
(75.6 \%) \\
340 / 535 \\
(63.6 \%)\end{array}$ & $\begin{array}{l}298 / 535 \\
(55.7 \%) \\
237 / 535 \\
(49.9 \%)\end{array}$ & $\begin{array}{l}382 / 535 \\
(71.4 \%) \\
322 / 535 \\
(60.2 \%)\end{array}$ \\
\hline
\end{tabular}

Abbreviations: N/A, no adequate data in relevant trials.

FOS, Fosaprepitant; APR, aprepitant; PAL, palonosetron; OND, ondansetron; GRA, granisetron: DXM, dexamethasone; NETU, netupitant; ROL, rolapitant;

CR, complete response; NN, no nausea; NV, no vomiting. 
the differences among triple antiemetic regimens have not yet been directly compared. Therefore, we evaluated several commonly used triple regimens with regard to $C R$, $\mathrm{NV}, \mathrm{NN}$ and safety.

\section{Complete response}

The results of our CR analysis revealed that NEPA may be the most effective regimen (absolute rank: 0.8579), though the efficacies of AOD and FOD ranked second and third (absolute rank 0.7564 and 0.7492 , respectively) and did not significantly differ from NEPA. Thus all three of these regimens generate a good CR. Notably, the absolute rank of PD was 0.7339 , and it exhibited a tendency to be more effective than AGD and RGD.

\section{Delayed vomiting}

Many studies have shown that NK-1 antagonists enhance the efficacy of 5-HT3 antagonists through induction or inhibition of substance $P$ [28-31]. However, these two types of drugs can be combined to form various triple regimens, and it is not yet clear whether the different combinations have different abilities to prevent delayed vomiting. NV analysis revealed that NEPA may be the most effective regimen (absolute rank:

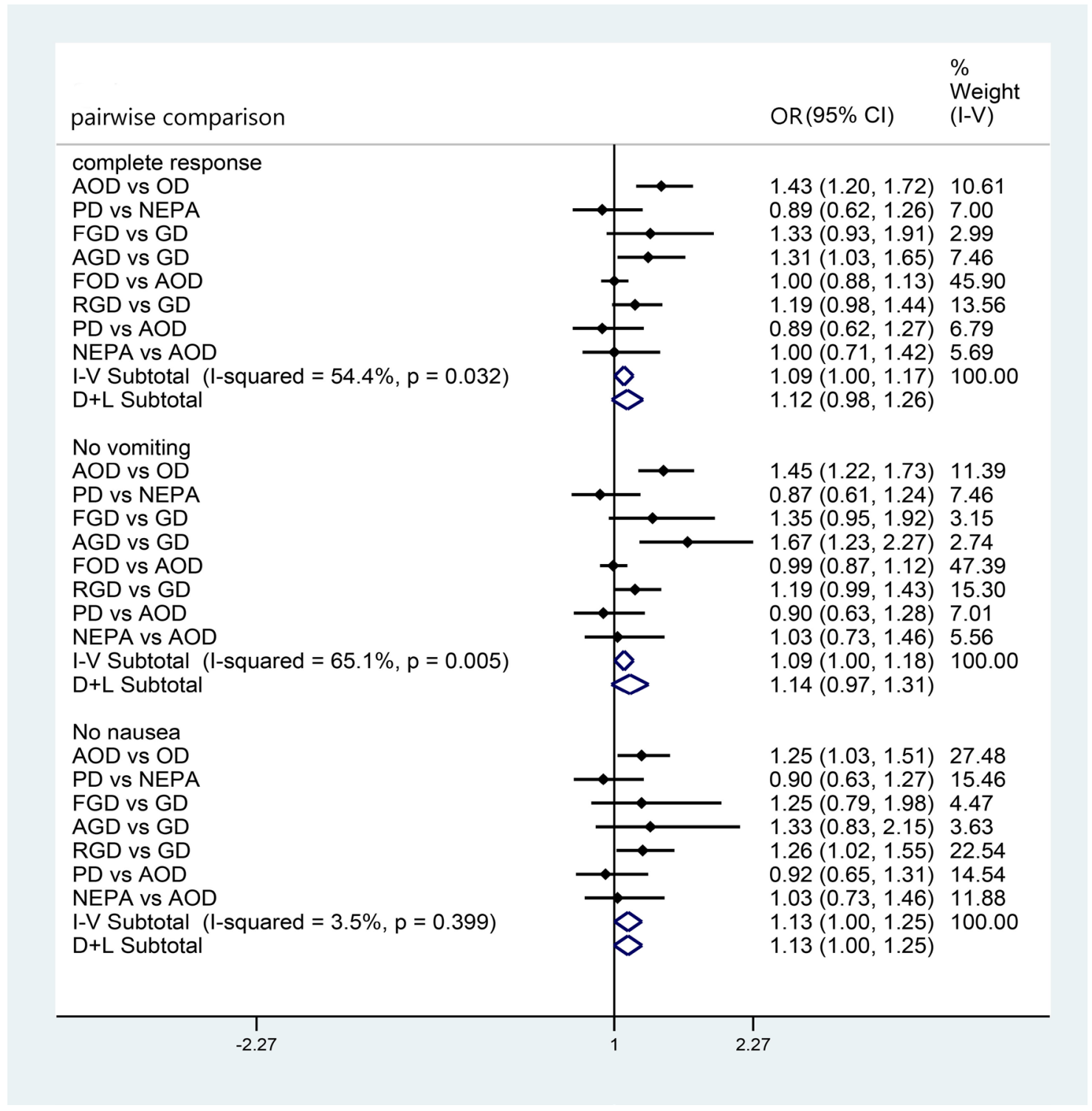

Figure 2: Meta-analysis of pairwise comparisons for effects on primary and secondary outcome. Direct comparison of included trials were analysed using a random effect model. Odd ratios and confidence intervals are shown on the right side of the table. $\mathrm{I}^{2}$ and $P$ values indicate the heterogeneity in each outcome. 
Table 2: Evaluation of consistency for primary outcome (complete response)

\begin{tabular}{l|c|c|c|c|c|c|c|}
\hline \multirow{2}{*}{ Side } & \multicolumn{2}{c}{ Direct } & \multicolumn{2}{c}{ Indirect } & \multicolumn{2}{c}{ Difference } & Coef \\
\cline { 2 - 7 } \multicolumn{1}{c|}{ Coef } & Std. Err. & \multicolumn{2}{c}{ Std. Err. } & Coef. & Std. Err. & P \\
\hline A E & -.7639229 & .1615678 & -.6257291 & 130.9475 & -.1381938 & 130.9476 & 0.999 \\
\hline B G & -.935809 & .1176838 & -.1210314 & 57.23982 & -.8147776 & 57.23995 & 0.989 \\
\hline B D & -.0035546 & .0949245 & -1.873384 & 145.1808 & 1.876939 & 145.1808 & 0.990 \\
\hline B F & .0248976 & .4128513 & -1.194039 & 187.4053 & 1.218937 & 187.4058 & 0.992 \\
\hline C H & -.8186631 & .3626814 & -2.037544 & 187.729 & 1.218881 & 187.7295 & 0.995 \\
\hline C E & -.6675231 & .2220261 & -.64144 & 148.881 & -.0260831 & 148.8811 & 1.000 \\
\hline E I & .5017233 & .1302082 & .7175594 & 153.7626 & -.2158361 & 153.7627 & 0.999 \\
\hline
\end{tabular}

This result is based on a node-splitting model. Direct estimates are always compared with indirect ones. If the $P$ value is $>0.05$, the comparison for this node is not inconsistent.

Abbreviations: Coef, regression coefficient; Std. Err., Standard error.

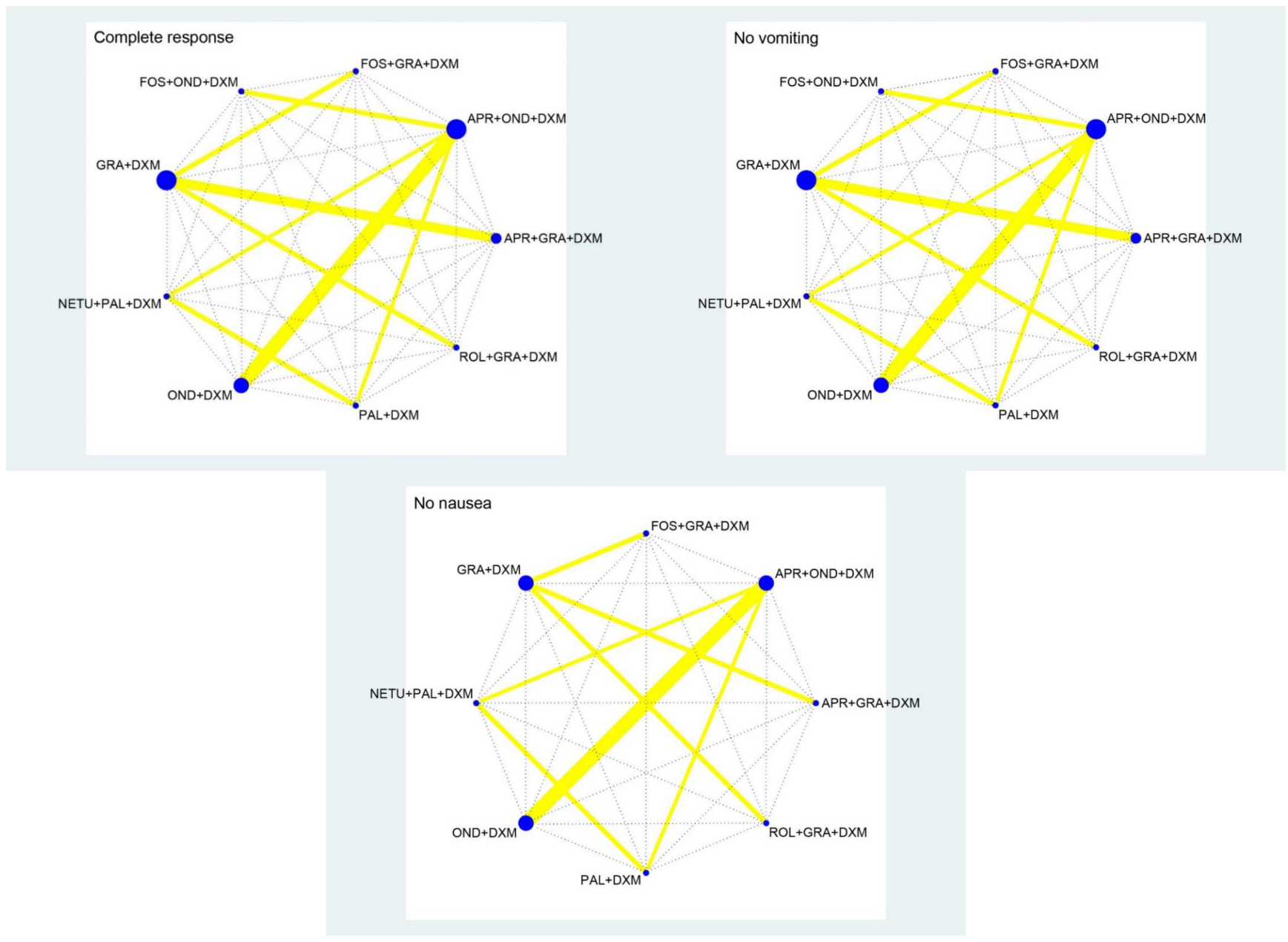

Figure 3: Network structures for all outcomes. Solid lines link treatments directly compared in trials, and dotted lines indicate the lack of a direct comparison between treatments. The thicknesses of the solid lines are proportional to the numbers of comparisons included in the network. The diameters of the circles are proportional to the numbers of studies involving specific treatments. Abbreviations: NEPA, NETU + PAL + DXM; AOD, APR + OND + DXM; FOD, FOS + OND + DXM; AGD, APR + GRA + DXM; PD, PAL + DXM; FGD, FOS + GRA + DXM; RGD = ROL + GRA + DXM; OD, OND + DXM; GD, GRA + DXM. 
0.8631 ) and that AOD and FOD are ranked second and third (absolute ranks: 0.7805 and 0.7668 , respectively). Furthermore, there were no obvious differences among the triple regimens evaluated, indicating that they do not significantly differ in their abilities to prevent delayed vomiting. Thus, among the regimens examined, the efficacy of NEPA appeared to be the best, but the other emetic regimens also produced good effects.

\section{Delayed nausea}

Delayed nausea has gradually become the focus of CINV research. The ability of an antiemetic regimen to preventing nausea may differ its ability to prevent vomiting because different mechanisms are involved [32]. NN analysis revealed that RGD ranked forth (absolute rank: 0.4759), whereas this regimen ranked seventh in NV analysis; thus RGD appears to have better effects against delayed nausea than delayed vomiting. In addition, NEPA was ranked first (absolute rank: 0.7902) in $\mathrm{NN}$ analysis, which indicates this regimen may be the most effective for preventing delayed nausea. However, no remarkable differences were detected among the triple regimens in the $\mathrm{NN}$ analysis, which suggests all of these regimens are similarly preventative against delayed nausea.

\begin{tabular}{|c|c|c|c|c|c|c|c|c|c|}
\hline & NEPA & AOD & FOD & PD & AGD & RGD & FGD & GD & OD \\
\hline NEPA & 0.8579 & $\begin{array}{l}1.9290 \\
(0.7477 \text { to } \\
5.6660)\end{array}$ & \begin{tabular}{|l|}
2.0090 \\
$(0.6768$ to \\
$7.0490)$ \\
\end{tabular} & \begin{tabular}{|l|}
2.1800 \\
$(0.8371$ to \\
$6.0040)$ \\
\end{tabular} & $\begin{array}{l}2.2740 \\
(0.7111 \text { to } \\
7.3170)\end{array}$ & \begin{tabular}{|l|}
2.7460 \\
$(0.9007$ to \\
$9.2580)$ \\
\end{tabular} & $\begin{array}{l}2.9080 \\
(0.8418 \text { to } \\
10.9100)\end{array}$ & \begin{tabular}{|l|}
4.9040 \\
$(1.6630$ to \\
$14.9300)^{*}$
\end{tabular} & $\begin{array}{l}5.5730 \\
(1.9080 \text { to } \\
18.1600)^{*}\end{array}$ \\
\hline AOD & $\begin{array}{l}0.5185 \\
(0.1765 \text { to } \\
1.3370)\end{array}$ & 0.7564 & $\begin{array}{l}1.0330 \\
(0.5903 \text { to } \\
2.0470)\end{array}$ & $\begin{array}{l}1.1340 \\
(0.4362 \text { to } \\
2.6440)\end{array}$ & $\begin{array}{l}1.1440 \\
(0.6158 \text { to } \\
2.2930)\end{array}$ & $\begin{array}{l}1.3860 \\
(0.7105 \text { to } \\
3.1090)\end{array}$ & $\begin{array}{l}1.4880 \\
(0.6930 \text { to } \\
3.3560)\end{array}$ & \begin{tabular}{|l|}
2.4810 \\
$(1.4960$ to \\
$4.4140)^{*}$
\end{tabular} & $\begin{array}{l}2.8500 \\
(1.9040 \text { to } \\
4.5230)^{*}\end{array}$ \\
\hline FOD & $\begin{array}{l}0.4978 \\
(0.1419 \text { to } \\
1.4770) \\
\end{array}$ & \begin{tabular}{|l|}
0.9679 \\
$(0.4885$ to \\
$1.6940)$ \\
\end{tabular} & 0.7492 & $\begin{array}{l}1.0950 \\
(0.3302 \text { to } \\
2.9270)\end{array}$ & $\begin{array}{l}1.0890 \\
(0.4982 \text { to } \\
2.6330) \\
\end{array}$ & $\begin{array}{l}1.3350 \\
(0.5459 \text { to } \\
3.4470) \\
\end{array}$ & $\begin{array}{l}1.4180 \\
(0.5823 \text { to } \\
3.6280) \\
\end{array}$ & \begin{tabular}{|l|}
2.3750 \\
$(1.1590$ to \\
$5.1770)^{*}$ \\
\end{tabular} & $\begin{array}{l}2.7530 \\
(1.4150 \text { to } \\
5.2120)^{*} \\
\end{array}$ \\
\hline PD & $\begin{array}{l}0.4587 \\
(0.1666 \text { to } \\
1.1950)\end{array}$ & $\begin{array}{l}0.8818 \\
(0.3782 \text { to } \\
2.2920)\end{array}$ & \begin{tabular}{|l|}
0.9130 \\
$(0.3416$ to \\
$3.0290)$
\end{tabular} & 0.7339 & $\begin{array}{l}1.0400 \\
(0.3596 \text { to } \\
2.9690)\end{array}$ & \begin{tabular}{|l|}
1.2470 \\
$(0.4545$ to \\
$3.8780)$
\end{tabular} & $\begin{array}{l}1.3260 \\
(0.4189 \text { to } \\
4.5170)\end{array}$ & \begin{tabular}{|l|}
2.2450 \\
$(0.8403$ to \\
$5.9940)$
\end{tabular} & $\begin{array}{l}2.5430 \\
(0.9583 \text { to } \\
7.4460)\end{array}$ \\
\hline AGD & $\begin{array}{l}0.4397 \\
(0.1367 \text { to } \\
1.4060)\end{array}$ & $\begin{array}{l}0.8744 \\
(0.4362 \text { to } \\
1.6240)\end{array}$ & \begin{tabular}{|l|}
0.9184 \\
$(0.3798$ to \\
$2.0070)$
\end{tabular} & \begin{tabular}{|l|}
0.9612 \\
$(0.3368$ to \\
$2.7810)$
\end{tabular} & 0.7277 & \begin{tabular}{|l|}
1.3350 \\
$(0.5459$ to \\
$3.4470)$
\end{tabular} & $\begin{array}{l}1.2930 \\
(0.5659 \text { to } \\
3.0130)\end{array}$ & \begin{tabular}{|l|}
2.1610 \\
$(1.2890$ to \\
$3.6750)^{*}$
\end{tabular} & \begin{tabular}{|l}
2.5270 \\
$(1.1920$ to \\
$4.8350)^{*}$
\end{tabular} \\
\hline RGD & $\begin{array}{l}0.3642 \\
(0.1080 \text { to } \\
1.1100)\end{array}$ & $\begin{array}{l}0.7213 \\
(0.3216 \text { to } \\
1.4070)\end{array}$ & \begin{tabular}{|l|}
0.7488 \\
$(0.2901$ to \\
$1.8320)$
\end{tabular} & \begin{tabular}{|l|}
0.8022 \\
$(0.2578$ to \\
$2.2000)$
\end{tabular} & $\begin{array}{l}0.8170 \\
(0.3788 \text { to } \\
1.7290)\end{array}$ & 0.6883 & $\begin{array}{l}1.0500 \\
(0.4280 \text { to } \\
2.7040)\end{array}$ & \begin{tabular}{|l|}
1.7610 \\
$(0.9455$ to \\
$3.3890)$
\end{tabular} & $\begin{array}{l}2.0640 \\
(0.8916 \text { to } \\
4.3980)\end{array}$ \\
\hline FGD & $\begin{array}{l}0.3439 \\
(0.0917 \text { to } \\
1.1880) \\
\end{array}$ & \begin{tabular}{|l|}
0.6719 \\
$(0.2979$ to \\
$1.4430)$ \\
\end{tabular} & \begin{tabular}{|l|}
0.7050 \\
$(0.2756$ to \\
$1.7170)$ \\
\end{tabular} & $\begin{array}{l}0.7541 \\
(0.2214 \text { to } \\
2.3870) \\
\end{array}$ & \begin{tabular}{|l}
0.7736 \\
$(0.3319$ to \\
$1.7670)$ \\
\end{tabular} & \begin{tabular}{|l|}
0.9527 \\
$(0.3699$ to \\
$2.3370)$ \\
\end{tabular} & 0.6740 & $\begin{array}{l}1.6790 \\
(0.8234 \text { to } \\
3.3330) \\
\end{array}$ & $\begin{array}{l}1.9250 \\
(0.8423 \text { to } \\
4.1910)\end{array}$ \\
\hline GD & $\begin{array}{l}0.2039 \\
(0.0670 \text { to } \\
0.6014)^{*}\end{array}$ & $\begin{array}{l}0.4031 \\
(0.2265 \text { to } \\
0.6683)^{*}\end{array}$ & $\begin{array}{l}0.4211 \\
(0.1931 \text { to } \\
0.8632)^{*} \\
\end{array}$ & $\begin{array}{l}0.4453 \\
(0.1668 \text { to } \\
1.1900)\end{array}$ & $\begin{array}{l}0.4626 \\
(0.2721 \text { to } \\
0.7760)^{*}\end{array}$ & \begin{tabular}{|l|}
0.5678 \\
$(0.2951$ to \\
$1.0580)$
\end{tabular} & $\begin{array}{l}0.5957 \\
(0.3001 \text { to } \\
1.2140)\end{array}$ & 0.5527 & $\begin{array}{l}1.1680 \\
(0.6021 \text { to } \\
1.9820)\end{array}$ \\
\hline OD & $\begin{array}{l}0.1794 \\
(0.0551 \text { to } \\
0.5242)^{*}\end{array}$ & $\begin{array}{l}0.3508 \\
(0.2211 \text { to } \\
0.5251)^{*}\end{array}$ & $\begin{array}{l}0.3633 \\
(0.1919 \text { to } \\
0.7066)^{*}\end{array}$ & $\begin{array}{l}0.3932 \\
(0.1343 \text { to } \\
1.0440)\end{array}$ & $\begin{array}{l}0.3958 \\
(0.2068 \text { to } \\
0.8388)^{*}\end{array}$ & \begin{tabular}{|l|}
0.4846 \\
$(0.2274$ to \\
$1.1220)$
\end{tabular} & $\begin{array}{l}0.5194 \\
(0.2386 \text { to } \\
1.1870)\end{array}$ & $\mid \begin{array}{l}0.8565 \\
(0.5044 \text { to } \\
1.6610)\end{array}$ & 0.5173 \\
\hline
\end{tabular}

Figure 4: Efficacy of antiemetic regimens for a complete response. Ranges in parentheses are $95 \%$ CIs. An OR more than 1 shows that the regimen listed in the left column is more beneficial than the one in the top row. Regimens are ordered according to their efficacy ranking. Absolute ranks are given in the diagonal. The larger the absolute rank, the better the treatment. Abbreviations, OD, ondansetron + dexamethasone; GD, granisetron + dexamethasone; PD, palanosetron + dexamethasone; AOD, aprepitant + ondansetron + dexamethasone; FOD, fosaprepitant + ondansetron + dexamethasone; AGD, aprepitant + granisetron + dexamethasone; FGD, fosaprepitant + granisetron + dexamethasone; NEPA, netupitant + palonosetron + dexamethasone; RGD, rolapitant + granisetron + dexamethasone. 


\section{Safety}

Because treatment-related adverse events often affect patients' tolerances, they are always included in evaluations of the safety of antiemetic regimens. Among these events, constipation, hiccups, asthenia, anorexia and diarrhea were the most commonly reported in previous studies [33]. We therefore focused on these five adverse events in our analyses.

With regard to constipation, the RGD and AGD regimens were associated with the lowest and highest incidences, respectively ( $0.4 \%$ and $23.9 \%$, respectively). The other triple regimens exhibited relatively small differences in the incidence of constipation. Gralla et al. and Aapro et al. [34, 35] reported that the incidences of constipation in patients treated with NEPA are 3.6\% and $2.1 \%$, respectively, which are similar to the value obtained for the RGD regimen in this study. With regard to hiccups, the RGD and AGD regimens were associated with the lowest and highest incidences, respectively $(0.6 \%$ and $35.5 \%$, respectively). The other triple regimens exhibited relatively small differences in their incidences of hiccups.

\begin{tabular}{|c|c|c|c|c|c|c|c|c|c|}
\hline & NEPA & AOD & FOD & AGD & PD & FGD & RGD & OD & GD \\
\hline NEPA & 0.8631 & $\begin{array}{l}1.7500 \\
(0.7147 \\
\text { to }\end{array}$ & $\begin{array}{l}1.8670 \\
(0.6218 \\
\text { to }\end{array}$ & $\begin{array}{l}2.1440 \\
(0.7043 \\
\text { to }\end{array}$ & $\begin{array}{l}2.5470 \\
(0.9489 \\
\text { to }\end{array}$ & $\begin{array}{l}3.0440 \\
10.9504 \\
\text { to }\end{array}$ & $\begin{array}{l}3.2130 \\
(0.9702 \\
\text { to }\end{array}$ & \begin{tabular}{|l|}
5.2310 \\
$(2.0140$ \\
to
\end{tabular} & \begin{tabular}{|l}
6.4310 \\
$(2.3460$ \\
to
\end{tabular} \\
\hline AOD & \begin{tabular}{|l}
0.5715 \\
0.1710 \\
to
\end{tabular} & 0.7805 & $\begin{array}{l}1.0730 \\
(0.5208 \\
\text { to }\end{array}$ & $\begin{array}{l}1.2290 \\
(0.5724 \\
\text { to }\end{array}$ & $\begin{array}{l}1.4610 \\
(0.5460 \\
\text { to }\end{array}$ & $\begin{array}{l}1.7380 \\
(0.7356 \\
\text { to }\end{array}$ & $\begin{array}{l}1.8550 \\
(0.6957 \\
\text { to }\end{array}$ & $\begin{array}{l}2.9890 \\
(1.9470 \\
\text { to }\end{array}$ & \begin{tabular}{|l}
3.6890 \\
$(2.0210$ \\
to
\end{tabular} \\
\hline FOD & $\begin{array}{l}0.5357 \\
0.1266 \\
\text { to }\end{array}$ & $\begin{array}{l}0.9324 \\
(0.4762 \\
\text { to }\end{array}$ & 0.7668 & $\begin{array}{l}1.1340 \\
(0.4528 \\
\text { to }\end{array}$ & $\begin{array}{l}1.3700 \\
(0.4036 \\
\text { to }\end{array}$ & $\begin{array}{l}1.6100 \\
(0.5964 \\
\text { to }\end{array}$ & $\begin{array}{l}1.7150 \\
(0.5261 \\
\text { to }\end{array}$ & $\begin{array}{l}2.7750 \\
(1.3780 \\
\text { to }\end{array}$ & $\begin{array}{l}3.3900 \\
(1.5050 \\
\text { to }\end{array}$ \\
\hline AGD & $\begin{array}{l}0.4665 \\
0.1117 \\
\text { to }\end{array}$ & $\begin{array}{l}0.8134 \\
(0.3694 \\
\text { to }\end{array}$ & $\begin{array}{l}0.8820 \\
(0.3072 \\
\text { to }\end{array}$ & 0.746 & $\begin{array}{l}1.1880 \\
(0.3519 \\
\text { to }\end{array}$ & $\begin{array}{l}1.4250 \\
(0.5766 \\
\text { to }\end{array}$ & $\begin{array}{l}1.5370 \\
(0.4703 \\
\text { to }\end{array}$ & $\begin{array}{l}2.4620 \\
(1.1630 \\
\text { to }\end{array}$ & $\begin{array}{l}2.9990 \\
(1.6050 \\
\text { to }\end{array}$ \\
\hline PD & $\begin{array}{l}0.3927 \\
0.1321 \\
\text { to }\end{array}$ & $\begin{array}{l}0.6846 \\
(0.3144 \\
\text { to }\end{array}$ & $\begin{array}{l}0.7302 \\
(0.2734 \\
\text { to }\end{array}$ & $\begin{array}{l}0.8417 \\
(0.3131 \\
\text { to }\end{array}$ & 0.7112 & $\begin{array}{l}1.1930 \\
(0.4135 \\
\text { to }\end{array}$ & $\begin{array}{l}1.2630 \\
(0.4220 \\
\text { to }\end{array}$ & $\begin{array}{l}2.0430 \\
(0.9017 \\
\text { to }\end{array}$ & $\begin{array}{l}2.5270 \\
(1.0560 \\
\text { to }\end{array}$ \\
\hline FGD & $\begin{array}{l}0.3285 \\
(0.0740 \\
\text { to }\end{array}$ & $\begin{array}{l}0.5753 \\
(0.2323 \\
\text { to }\end{array}$ & $\begin{array}{l}0.6209 \\
(0.2103 \\
\text { to }\end{array}$ & $\begin{array}{l}0.7016 \\
(0.2835 \\
\text { to }\end{array}$ & $\begin{array}{l}0.8381 \\
(0.2317 \\
\text { to }\end{array}$ & 0.6731 & $\begin{array}{l}1.0730 \\
(0.3167 \\
\text { to }\end{array}$ & $\begin{array}{l}1.7260 \\
(0.7069 \\
\text { to }\end{array}$ & $\begin{array}{l}2.1040 \\
(0.9962 \\
\text { to }\end{array}$ \\
\hline RGD & $\begin{array}{l}0.3113 \\
(0.0850 \\
\text { to }\end{array}$ & $\begin{array}{l}0.5391 \\
(0.2537 \\
\text { to }\end{array}$ & $\begin{array}{l}0.5832 \\
(0.2206 \\
\text { to }\end{array}$ & $\begin{array}{l}0.6508 \\
(0.2988 \\
\text { to }\end{array}$ & $\begin{array}{l}0.7918 \\
(0.2650 \\
\text { to }\end{array}$ & $\begin{array}{l}0.9323 \\
(0.3863 \\
\text { to }\end{array}$ & 0.6582 & $\begin{array}{l}1.6120 \\
(0.7539 \\
\text { to }\end{array}$ & $\begin{array}{l}1.9390 \\
(1.1080 \\
\text { to }\end{array}$ \\
\hline OD & $\begin{array}{l}0.1912 \\
(0.0508 \\
\text { to }\end{array}$ & $\begin{array}{l}0.3346 \\
(0.1988 \\
\text { to }\end{array}$ & $\begin{array}{l}0.3604 \\
0.1529 \\
\text { to }\end{array}$ & $\begin{array}{l}0.4061 \\
(0.1910 \\
\text { to }\end{array}$ & $\begin{array}{l}0.4894 \\
(0.1595 \\
\text { to }\end{array}$ & $\begin{array}{l}0.5792 \\
(0.2360 \\
\text { to }\end{array}$ & $\begin{array}{l}0.6204 \\
(0.2099 \\
\text { to }\end{array}$ & 0.5418 & $\begin{array}{l}1.2210 \\
(0.6446 \\
\text { to }\end{array}$ \\
\hline GD & $\begin{array}{l}0.1555 \\
0.0430 \\
\text { to }\end{array}$ & $\begin{array}{l}0.2711 \\
(0.1518 \\
\text { to } \\
\end{array}$ & \begin{tabular}{|l}
0.2949 \\
$(0.1225$ \\
to \\
\end{tabular} & $\begin{array}{l}0.3334 \\
(0.1852 \\
\text { to } \\
\end{array}$ & $\begin{array}{l}0.3956 \\
0.1395 \\
\text { to } \\
\end{array}$ & $\begin{array}{l}0.4753 \\
(0.2301 \\
\text { to }\end{array}$ & $\begin{array}{l}0.5157 \\
(0.2004 \\
\text { to }\end{array}$ & $\begin{array}{l}0.8190 \\
(0.4473 \\
\text { to }\end{array}$ & 0.4932 \\
\hline
\end{tabular}

Figure 5: Efficacy of antiemetic regimens for no vomiting. Ranges in parentheses are $95 \%$ CIs. An OR more than 1 shows that the regimen listed in the left column is more beneficial than the one in the top row. Regimens are ordered according to their efficacy ranking. Absolute ranks are given in the diagonal. The larger the absolutely rank, the better the treatment. Abbreviations: OD, ondansetron + dexamethasone; GD, granisetron + dexamethasone; $\mathrm{PD}$, palanosetron + dexamethasone; AOD, aprepitant + ondansetron + dexamethasone; FOD, fosaprepitant + ondansetron + dexamethasone; AGD, aprepitant + granisetron + dexamethasone; FGD, fosaprepitant + granisetron + dexamethasone; NEPA, netupitant + palonosetron + dexamethasone; RGD, rolapitant + granisetron + dexamethasone. 
The RGD regimen was also associated with the lowest incidence asthenia (0.4\%). No information regarding the incidence of asthenia associated with NEPA was available from the included studies; however, Calcagnile et al. and Lanzarotti et al. [36, 37] reported incidences of $10 \%$ and $13.9 \%$, respectively, which are similar to the other triple regimens in this study. The NEPA and AGD regimens were respectively associated with the lowest and highest incidences of anorexia ( $0.7 \%$ and $36.3 \%$, respectively). The incidences of anorexia did not significantly differ among the other triple regimens. Finally, the incidences of diarrhea among all of the triple regimens ranged from $7.8 \%$ to $12.6 \%$, and the differences among them were not significant.

Overall, based on the incidences of adverse events, we hypothesize that the best compliance rate would be achieved by treating patients with RGD. Previous reports indicate that rolapitant differs from other NK-1 antagonists [37-40] in that it is not metabolized by CYP P450 3A4 (CYP3A4) [41, 42]. Consequently, this drug likely avoids drug-drug interactions and potential adverse events [43, 44]. Patients treated with NEPA also showed good compliance. By contrast, among all of the triple regimens evaluated, patients treated with AGD had the most difficulty achieving good compliance.

\section{Limitations}

Previous studies have shown that patients with osteosarcoma or soft tissue sarcoma do not respond to NK-1 + 5-HT3 + DXM regimens, suggesting the efficacies of triple regimens for preventing CINV may be related to

\begin{tabular}{|c|c|c|c|c|c|c|c|c|}
\hline & NEPA & PD & AOD & RGD & OD & AGD & FGD & GD \\
\hline NEPA & 0.7902 & $\begin{array}{l}1.9940 \\
(0.3812 \text { to } \\
10.0400)\end{array}$ & $\begin{array}{l}2.2150 \\
(0.6267 \text { to } \\
13.4200)\end{array}$ & $\begin{array}{l}4.2990 \\
(0.7141 \text { to } \\
33.4000)\end{array}$ & $\begin{array}{l}4.1680 \\
(0.9983 \text { to } \\
31.9300)\end{array}$ & $\begin{array}{l}6.0260 \\
(0.9760 \text { to } \\
56.2100)\end{array}$ & $\begin{array}{l}7.0210 \\
(1.0610 \text { to } \\
65.3300)\end{array}$ & $\begin{array}{l}7.9160 \\
(1.6380 \text { to } \\
58.3700)\end{array}$ \\
\hline PD & \begin{tabular}{|l|}
0.5015 \\
$(0.0996$ to \\
$2.6230)$
\end{tabular} & 0.6569 & $\begin{array}{l}1.1210 \\
(0.3434 \text { to } \\
5.7370)\end{array}$ & \begin{tabular}{|l}
2.1530 \\
$(0.4194$ to \\
$15.6000)$
\end{tabular} & \begin{tabular}{|l|}
2.0930 \\
$(0.5501$ to \\
$13.4900)$
\end{tabular} & $\begin{array}{l}3.0630 \\
(0.4997 \text { to } \\
25.6500)\end{array}$ & \begin{tabular}{|l}
3.5680 \\
$(0.5736$ to \\
$28.7300)$
\end{tabular} & \begin{tabular}{|l}
4.0450 \\
$(0.8418$ to \\
$24.7200)$
\end{tabular} \\
\hline AOD & $\mid \begin{array}{l}0.4515 \\
(0.0745 \text { to } \\
1.5960)\end{array}$ & $\mid \begin{array}{l}0.8924 \\
(0.1743 \text { to } \\
2.9120)\end{array}$ & 0.6276 & $\begin{array}{l}1.8320 \\
(0.4697 \text { to } \\
7.6410)\end{array}$ & $\mid \begin{array}{l}1.8410 \\
(0.9335 \text { to } \\
4.4990)\end{array}$ & \begin{tabular}{|l}
2.7220 \\
$(0.6365$ to \\
$11.7700)$
\end{tabular} & \begin{tabular}{|l}
3.1030 \\
$(0.7770$ to \\
$13.2000)$
\end{tabular} & \begin{tabular}{|l}
3.4850 \\
$(1.2250$ to \\
$10.8300)$
\end{tabular} \\
\hline RGD & \begin{tabular}{|l|}
0.2326 \\
$(0.0299$ to \\
$1.4000)$
\end{tabular} & $\begin{array}{l}0.4644 \\
(0.0641 \text { to } \\
2.3840)\end{array}$ & \begin{tabular}{|l}
1.1210 \\
$(0.3434$ to \\
$5.7370)$
\end{tabular} & 0.4759 & $\begin{array}{l}1.0360 \\
(0.2052 \text { to } \\
4.6970)\end{array}$ & $\begin{array}{l}1.4010 \\
(0.3070 \text { to } \\
7.7640)\end{array}$ & $\begin{array}{l}1.6020 \\
(0.3419 \text { to } \\
8.7600)\end{array}$ & \begin{tabular}{|l}
1.8230 \\
$(0.5337$ to \\
$6.9820)$
\end{tabular} \\
\hline OD & $\begin{array}{l}0.2399 \\
(0.0313 \text { to } \\
1.0020)\end{array}$ & $\begin{array}{l}0.4778 \\
(0.0742 \text { to } \\
1.8180)\end{array}$ & $\begin{array}{l}0.5433 \\
(0.2223 \text { to } \\
1.0710)\end{array}$ & $\begin{array}{l}0.9651 \\
(0.2129 \text { to } \\
4.8740)\end{array}$ & 0.4699 & $\begin{array}{l}1.4360 \\
(0.3230 \text { to } \\
6.4470)\end{array}$ & $\begin{array}{l}1.6320 \\
(0.3864 \text { to } \\
6.7550)\end{array}$ & $\begin{array}{l}1.8120 \\
(0.6216 \text { to } \\
6.0420)\end{array}$ \\
\hline AGD & \begin{tabular}{|l|}
0.1659 \\
$(0.0178$ to \\
$1.0250)$
\end{tabular} & $\begin{array}{l}0.3264 \\
(0.0390 \text { to } \\
2.0010)\end{array}$ & $\begin{array}{l}0.3673 \\
(0.0850 \text { to } \\
1.5710)\end{array}$ & $\begin{array}{l}0.7135 \\
(0.1288 \text { to } \\
3.2570)\end{array}$ & $\begin{array}{l}0.6966 \\
(0.1551 \text { to } \\
3.0960)\end{array}$ & 0.3853 & $\begin{array}{l}1.1540 \\
(0.2197 \text { to } \\
5.9950)\end{array}$ & $\begin{array}{l}1.3310 \\
(0.3392 \text { to } \\
4.1160)\end{array}$ \\
\hline FGD & $\begin{array}{l}0.1424 \\
(0.0153 \text { to } \\
0.9429)\end{array}$ & $\begin{array}{l}0.2803 \\
(0.0348 \text { to } \\
1.7430)\end{array}$ & $\begin{array}{l}0.3223 \\
(0.0758 \text { to } \\
1.2870)\end{array}$ & $\begin{array}{l}0.6244 \\
(0.1141 \text { to } \\
2.9250)\end{array}$ & \begin{tabular}{|l|}
0.6127 \\
$(0.1480$ to \\
$2.5880)$
\end{tabular} & $\begin{array}{l}0.8669 \\
(0.1668 \text { to } \\
4.5520)\end{array}$ & 0.3545 & $\begin{array}{l}1.1600 \\
(0.2926 \text { to } \\
3.6500)\end{array}$ \\
\hline GD & \begin{tabular}{|l|}
0.1263 \\
$(0.0171$ to \\
$0.6106)$
\end{tabular} & \begin{tabular}{|l|}
0.2472 \\
$(0.0404$ to \\
$1.1880)$
\end{tabular} & \begin{tabular}{|l|}
0.2869 \\
$(0.0923$ to \\
$0.8161)$
\end{tabular} & \begin{tabular}{|l}
0.5486 \\
$(0.1432$ to \\
$1.8740)$
\end{tabular} & \begin{tabular}{|l}
0.5518 \\
$(0.1655$ to \\
$1.6090)$
\end{tabular} & \begin{tabular}{|l}
0.7514 \\
$(0.2429$ to \\
$2.9480)$
\end{tabular} & $\begin{array}{l}0.8621 \\
(0.2740 \text { to } \\
3.4170)\end{array}$ & 0.3239 \\
\hline
\end{tabular}

Figure 6: Efficacy of antiemetic regimens for no nausea. Ranges in parentheses are 95\%CIs. An OR more than 1 shows that the regimen listed in the left column is more beneficial than the one in the top row. Regimens are ordered according to their efficacy ranking. Absolute ranks are given in the diagonal. The larger the absolute rank, the better the treatment. Abbreviations: OD, ondansetron + dexamethasone; GD, granisetron + dexamethasone; PD, palanosetron + dexamethasone; AOD, aprepitant + ondansetron + dexamethasone; AGD, aprepitant + granisetron + dexamethasone; FGD, fosaprepitant + granisetron + dexamethasone; NEPA, netupitant + palonosetron + dexamethasone; RGD, rolapitant + granisetron + dexamethasone. 
Table 3: Incidence of adverse events in patients treated with different triple antiemetic regimens

\begin{tabular}{|l|c|c|c|c|c|c|c|c|c|c|c|}
\hline Regimen & \multicolumn{1}{c}{ Constipation } & $\mathbf{\%}$ & \multicolumn{1}{c}{ Hiccups } & $\mathbf{\%}$ & \multicolumn{1}{c}{ Asthenia } & $\mathbf{\%}$ & \multicolumn{1}{c}{ Anorexia } & $\%$ & \multicolumn{1}{c}{ Diarrhea } & $\%$ \\
\hline OD & $95 / 761$ & 12.5 & $37 / 476$ & 7.8 & $101 / 761$ & 13.3 & $62 / 497$ & 12.5 & $55 / 497$ & 11.1 \\
\hline AOD & $198 / 1926$ & 10.3 & $136 / 1778$ & 7.6 & $276 / 1926$ & 14.3 & $175 / 1799$ & 9.7 & $160 / 1665$ & 9.6 \\
\hline GD & $105 / 948$ & 11.1 & $127 / 1158$ & 11 & $40 / 837$ & 4.8 & $100 / 241$ & 41.5 & $61 / 451$ & 13.5 \\
\hline FGD & $23 / 174$ & 13.2 & $15 / 174$ & 8.6 & N/A & N/A & N/A & N/A & N/A & N/A \\
\hline AGD & $105 / 439$ & 23.9 & $83 / 234$ & 35.5 & $31 / 289$ & 10.7 & $85 / 234$ & 36.3 & $56 / 445$ & 12.6 \\
\hline PD & N/A & N/A & $5 / 136$ & 3.7 & N/A & N/A & $3 / 136$ & 2.2 & N/A & N/A \\
\hline FOD & $121 / 1143$ & 10.6 & $64 / 1143$ & 5.6 & $98 / 1143$ & 8.6 & $76 / 1143$ & 6.7 & $89 / 1143$ & 7.8 \\
\hline NEPA & N/A & N/A & $7 / 136$ & 5.1 & N/A & N/A & $1 / 136$ & 0.7 & N/A & N/A \\
\hline RGD & $2 / 535$ & 0.4 & $3 / 535$ & 0.6 & $2 / 535$ & 0.4 & N/A & N/A & N/A & N/A \\
\hline Total & $649 / 5926$ & $11.0 \%$ & $540 / 5770$ & $9.4 \%$ & $548 / 5491$ & $10 \%$ & $502 / 4186$ & $12.0 \%$ & $421 / 4201$ & $10.0 \%$ \\
\hline
\end{tabular}

Shown are the incidences of adverse events in patients treated with the indicated regimens. Total incidences of constipation, hiccups, asthenia, anorexia and diarrhea are shown at the bottom of the table. N/A, no adequate data in relevant trials.

NEPA, NETU + PAL + DXM; AOD, APR + OND + DXM; FOD, FOS + OND + DXM; AGD, APR + GRA + DXM; PD, PAL + DXM; FGD, FOS + GRA + DXM; RGD = ROL + GRA + DXM; OD, OND + DXM; GD, GRA + DXM.

the cancer type $[45,46]$. We could not perform subgroup analysis of specific cancer types because data on cancer types were lacking in the included studies. Thus, we could not clearly determine whether the efficacies of the triple regimens differed based on the cancer type.

\section{MATERIALS AND METHODS}

\section{Search}

This meta-analysis was conducted in accordance with the Preferred Reporting Items for Systematic Reviews and Meta-Analyses (PRISMA) guidelines $[47,48]$. A comprehensive literature search of the PubMed, MEDLINE, EMBASE, and the Cochrane Library databases was performed. We used the terms "cisplatin", "CINV" or "chemotherapy induced nausea and vomiting" in combination with "highly emetogenic chemotherapy" and "randomized controlled clinical trials" to identify studies related to CINV. Additionally, we reviewed the reference lists of all meta-analyses and other publications as potential data sources. When data or study characteristics were not reported in the primary publication, we searched clinical trial reports, trial registries and drug company websites to obtain additional data. When possible, we used data from intention-to-treat (ITT) analyses for all randomly assigned participants.

\section{Inclusion criteria}

The eligibility criteria included enrollment of patients receiving cisplatin-containing chemotherapy.
Trials were excluded if: 1) they were not randomized; 2) the intervention was not relevant to cisplatin-based chemotherapy; 3) no triple regimen was assessed; 4) they were published in a language other than English; or 5) the trial results were not relevant to delayed nausea and vomiting. Two independent reviewers screened all of the retrieved references based on these predefined exclusion criteria. A two-round process was used; titles and abstracts were screened for potential relevance prior to reviewing full text publications.

\section{Data extraction}

Two researchers independently extracted the following data from each eligible study: the first author, year of publication, trial design, intervention, outcome indicator, and numbers of cases and controls. To ensure accuracy of the data, inconsistencies were discussed by the researchers so as to reach a consensus.

\section{Risk of bias assessment}

We assessed the included studies using The Cochrane Collaboration's "Risk of bias (RoB)" tool outlined in Table 8.5c of the Cochrane Handbook for Systematic Reviews of Interventions, after which the assessment was checked by a second review author. We considered adequate sequence generation and allocation concealment to be most important in this assessment; therefore, a judgment of low risk was desirable for these domains for all trials. Blinding was not appropriate due to the nature of the treatments, and any issues regarding the 
reporting of incomplete outcome data, selective outcome reporting, or attrition bias were overcome by the collection of individual studies.

\section{Quality assessment}

We assessed the quality of each study according to quality assessment criteria (Jadad scale). The quality scores of the studies ranged from 0 (lowest) to 5 (highest). Studies with scores of less than 2 were considered low quality, and those with scores equal to or greater than 3 were regarded as high quality.

\section{Data analysis}

We performed traditional pairwise meta-analysis for direct treatment comparisons. As all of the results were extracted as binary outcomes, we calculated the summary effect sizes as odds ratios (ORs) with 95\% confidence intervals. The statistical heterogeneity among studies was assessed using Cochran's $Q$ test and the $I^{2}$ statistic [49]. A $P$ value of 0.10 or less for the $Q$ test or an $I^{2}$ value of greater than $50 \%$ was suggestive of substantial between-study heterogeneity. If heterogeneity was detected, we performed a sensitivity analysis to explore the potential sources of the heterogeneity.

We analyzed the pooled data for all antiemetic regimens using a fixed effects model within a Bayesian framework with the pcnetmeta package of $\mathrm{R}$ project [50]. All models were run with 1000 burn-in iterations and at least 50,000 inference iterations [51]. Summary effect sizes were calculated as ORs with $95 \%$ creditable intervals [50]. To assess the efficacies of the different regimens, we also calculated their absolute ranks. The resultant rankings are presented graphically.

We also analyzed inconsistencies between the direct and indirect estimates for the primary outcome. Differences between these estimates were detected using a node-splitting model, which used different parameters to divide the comparisons. The model then jointly estimated the two parameters and reported the difference. Finally, the model tested whether the real difference was zero [52].

For traditional meta-analyses we used Stata 14.0. For network meta-analyses we used JAGS, Stata 14.0 and $\mathrm{R}$ project.

\section{CONCLUSIONS}

With respect to $\mathrm{CR}, \mathrm{NV}$ and $\mathrm{NN}$, NEPA had the best preventive effect against cisplatin-based chemotherapy-induced delayed nausea and vomiting. The safety of NEPA was also better, making it worthy of recommendation. AOD ranked second, second and third, respectively, for $\mathrm{CR}, \mathrm{NV}$ and $\mathrm{NN}$, which also indicates superior preventative effects. From an economic perspective, although the safety of AOD has not been shown to be advantageous, this regimen is also worthy of recommendation because of its low cost. And although RGD offers no advantage with respect to delayed vomiting, it effectively prevents delayed nausea and is relatively safe to use. Thus, the RGD regimen deserves the attention of clinicians and patients for its ability to prevent severe constipation, hiccups, asthenia and/or delayed nausea.

\section{ACKNOWLEDGMENTS AND FUNDING}

Qi Shi's work on this paper was supported in part by the Scientific Research Foundation of Traditional Chinese Medicine of the Shanghai Health Bureau (2014LZ079A), the Scientific Research Foundation of the Shanghai Health Bureau (20134117) and the Scientific Research Plan Project of the Shanghai Science and Technology Committee (14401930800).

\section{CONFLICTS OF INTEREST}

The authors have no conflicts of interest.

\section{REFERENCES}

1. Hickok JT, Roscoe JA, Morrow GR, King DK, Atkins JN, Fitch TR. Nausea and emesis remain significant problems of chemotherapy despite prophylaxis with 5-hydroxytryptamine-3 antiemetics: a University of Rochester James P. Wilmot Cancer Center Community Clinical Oncology Program Study of 360 cancer patients treated in the community. Cancer. 2003; 97:2880-2886.

2. Wiser W, Berger A. Practical management of chemotherapyinduced nausea and vomiting. Oncology (Williston Park). 2005; 19:637-645.

3. Abramovitz RB, Gaertner KM. The role of netupitant and palonosetron in chemotherapy-induced nausea and vomiting. J Oncol Pharm Pract. 2016; 22:477-84. doi: $10.1177 / 1078155215581525$.

4. Navari R. The current status of the use of palonosetron. Expert Opin Pharmacother. 2013; 14:1281-1284.

5. Longo F, Mansueto G, Lapadula V, De Sanctis R, Quadrini S, Grande R, Gori B, Altavilla A, D’Antoni I, Del Signore E, Stumbo L, De Luca C, Cimadon B, et al. Palonosetron plus 3-day aprepitant and dexamethasone to prevent nausea and vomiting in patients receiving highly emetogenic chemotherapy. Support Care Cancer. 2011; 19:1159-1164.

6. Hickok JT, Roscoe JA, Morrow GR, Bole CW, Zhao H, Hoelzer KL, Dakhil SR, Moore T, Fitch TR. 5-Hydroxytryptamine-receptor antagonists versus prochlorperazine for control of delayed nausea caused by doxorubicin: a URCC CCOP randomised controlled trial. Lancet Oncol. 2005; 6:765-772.

7. Grunberg SM, Deuson RR, Mavros P, Geling O, Hansen M, Cruciani G, Daniele B, De Pouvourville G, Rubenstein EB, 
Daugaard G. Incidence of chemotherapy-induced nausea and emesis after modern antiemetics. Cancer. 2004; 100: 2261-2268.

8. Aapro MS. Palonosetron as an anti-emetic and anti-nausea agent in oncology. Ther Clin Risk Manag. 2007; 3:1009-1020.

9. Roscoe JA, Morrow GR, Colagiuri B, Heckler CE, Pudlo BD, Colman L, Hoelzer K, Jacobs A. Insight in the prediction of chemotherapy-induced nausea. Support Care Cancer. 2010; 18:869-876.

10. Hesketh PJ, Kris MG, Grunberg SM, Beck T, Hainsworth JD, Harker G, Aapro MS, Gandara D, Lindley CM. Proposal for classifying the acute emetogenicity of cancer chemotherapy. J Clin Oncol. 1997; 15:103-109.

11. Grunberg SM, Warr D, Gralla RJ, Rapoport BL, Hesketh PJ, Jordan K, Espersen BT. Evaluation of new antiemetic agents and definition of antineoplastic agent emetogenicity - state of the art. Support Care Cancer. 2011; 19:S43-47.

12. Hesketh PJ, Grunberg SM, Gralla RJ, Warr DG, Roila F, de Wit R, Chawla SP, Carides AD, Ianus J, Elmer ME, Evans JK, Beck K, Reines S, et al. The oral neurokinin-1 antagonist aprepitant for the prevention of chemotherapyinduced nausea and vomiting: a multinational, randomized, double-blind, placebo-controlled trial in patients receiving high-dose cisplatin - the Aprepitant Protocol 052 Study Group. J Clin Oncol. 2003; 21:4112-4119.

13. Chawla SP, Grunberg SM, Gralla RJ, Hesketh PJ, Rittenberg C, Elmer ME, Schmidt C, Taylor A, Carides AD, Evans JK, Horgan KJ. Establishing the dose of the oral NK1 antagonist aprepitant for the prevention of chemotherapyinduced nausea and vomiting. Cancer. 2003; 97:2290-2300.

14. Campos D, Pereira JR, Reinhardt RR, Carracedo C, Poli S, Vogel C, Martinez-Cedillo J, Erazo A, Wittreich J, Eriksson LO, Carides AD, Gertz BJ. Prevention of cisplatininduced emesis by the oral neurokinin-1 antagonist, MK-869, in combination with granisetron and dexamethasone or with dexamethasone alone. J Clin Oncol. 2001; 19:1759-1767.

15. Poli-Bigelli S, Rodrigues-Pereira J, Carides AD, Julie Ma G, Eldridge K, Hipple A, Evans JK, Horgan KJ, Lawson F. Addition of the neurokinin 1 receptor antagonist aprepitant to standard antiemetic therapy improves control of chemotherapy-induced nausea and vomiting. Results from a randomized, double-blind, placebo-controlled trial in Latin America. Cancer. 2003; 97:3090-3098.

16. Hesketh PJ, Rossi G, Rizzi G, Palmas M, Alyasova A, Bondarenko I, Lisyanskaya A, Gralla RJ: Efficacy and safety of NEPA, an oral combination of netupitant and palonosetron, for prevention of chemotherapy-induced nausea and vomiting following highly emetogenic chemotherapy: a randomized dose-ranging pivotal study. Ann Oncol. 2014; 25:1340-1346.

17. Saito H, Yoshizawa H, Yoshimori K, Katakami N, Katsumata N, Kawahara M, Eguchi K. Efficacy and safety of single-dose fosaprepitant in the prevention of chemotherapyinduced nausea and vomiting in patients receiving high-dose cisplatin: a multicentre, randomised, double-blind, placebocontrolled phase 3 trial. Ann Oncol. 2013; 24:1067-1073.
18. Takahashi T, Hoshi E, Takagi M, Katsumata N, Kawahara M, Eguchi K. Multicenter, phase II, placebo-controlled, double-blind, randomized study of aprepitant in Japanese patients receiving high-dose cisplatin. Cancer Sci. 2010; 101: 2455-2461.

19. Hu Z, Cheng Y, Zhang H, Zhou C, Han B, Zhang Y, Huang C, Chang J, Song X, Liang J, Liang H, Bai C, Yu S. Aprepitant triple therapy for the prevention of chemotherapy-induced nausea and vomiting following high-dose cisplatin in Chinese patients: a randomized, double-blind, placebo-controlled phase III trial. Support Care Cancer. 2014; 22:979-987.

20. Grunberg S, Chua D, Maru A, Dinis J, DeVandry S, Boice JA, Hardwick JS, Beckford E, Taylor A, Carides A, Roila F, Herrstedt J. Single-dose fosaprepitant for the prevention of chemotherapy-induced nausea and vomiting associated with cisplatin therapy: randomized, double-blind study protocol-EASE. J Clin Oncol. 2011; 29:1495-1501.

21. Rapoport BL, Chasen MR, Gridelli C, Urban L, Modiano MR, Schnadig ID, Poma A, Arora S, Kansra V, Schwartzberg LS, Navari RM. Safety and efficacy of rolapitant for prevention of chemotherapy-induced nausea and vomiting after administration of cisplatin-based highly emetogenic chemotherapy in patients with cancer: two randomised, active-controlled, double-blind, phase 3 trials. Lancet Oncol. 2015; 16:1079-89.

22. dos Santos LV, Souza FH, Brunetto AT, Sasse AD, da Silveira Nogueira Lima JP. Neurokinin-1 receptor antagonists for chemotherapy-induced nausea and vomiting: a systematic review. J Natl Cancer Inst. 2012; 104:1280-1292.

23. Chapell R, Aapro MS. Efficacy of aprepitant among patients aged 65 and over receiving moderately to highly emetogenic chemotherapy: a meta-analysis of unpublished data from previously published studies. J Geriatr Oncol. 2013; 4:78-83.

24. Fang ZW, Zhai SD. A meta-analysis of aprepitant for prevention of chemotherapy-induced nausea and vomiting [Article in Chinese]. Beijing Da Xue Xue Bao. 2010; 42:756-763.

25. Wang X, Wang L, Wang H, Zhang H. Effectiveness of Olanzapine Combined with Ondansetron in Prevention of Chemotherapy-Induced Nausea and Vomiting of Non-small Cell Lung Cancer. Cell Biochem Biophys. 2015; PMID: 25567657.

26. Navari RM, Gray SE, Kerr AC. Olanzapine versus aprepitant for the prevention of chemotherapy-induced nausea and vomiting: a randomized phase III trial. J Support Oncol. 2011; 9:188-195.

27. Schwartzberg LS, Modiano MR, Rapoport BL, Chasen MR, Gridelli C, Urban L, Poma A, Arora S, Navari RM, Schnadig ID. Safety and efficacy of rolapitant for prevention of chemotherapy-induced nausea and vomiting after administration of moderately emetogenic chemotherapy or anthracycline and cyclophosphamide regimens in patients with cancer: a randomised, active-controlled, double-blind, phase 3 trial. Lancet Oncol. 2015; 16:1071-8. 
28. Stathis M, Pietra C, Rojas C, Slusher BS. Inhibition of substance P-mediated responses in NG108-15 cells by netupitant and palonosetron exhibit synergistic effects. Eur J Pharmacol. 2012; 689:25-30.

29. Thomas AG, Stathis M, Rojas C, Slusher BS. Netupitant and palonosetron trigger NK1 receptor internalization in NG108-15 cells. Exp Brain Res. 2014; 232:2637-2644.

30. Rojas C, Raje M, Tsukamoto T, Slusher BS. Molecular mechanisms of 5-HT(3) and $\mathrm{NK}(1)$ receptor antagonists in prevention of emesis. Eur J Pharmacol. 2014; 722:26-37.

31. Grunberg SM, Slusher B, Rugo HS. Emerging treatments in chemotherapy-induced nausea and vomiting. Clin Adv Hematol Oncol. 2013; 11:1-18; quiz 2 p following 18.

32. National Comprehensive Cancer Network I. NCCN Guidelines Version 1.2015:Antiemesis. 2015.

33. Dando TM, Perry CM. Aprepitant: a review of its use in the prevention of chemotherapy-induced nausea and vomiting. Drugs. 2004; 64:777-794.

34. Gralla RJ, Bosnjak SM, Hontsa A, Balser C, Rizzi G, Rossi G, Borroni ME, Jordan K. A phase III study evaluating the safety and efficacy of NEPA, a fixed-dose combination of netupitant and palonosetron, for prevention of chemotherapyinduced nausea and vomiting over repeated cycles of chemotherapy. Ann Oncol. 2014; 25:1333-1339.

35. Aapro M, Rugo H, Rossi G, Rizzi G, Borroni ME, Bondarenko I, Sarosiek T, Oprean C, Cardona-Huerta S, Lorusso V, Karthaus M, Schwartzberg L, Grunberg S. A randomized phase III study evaluating the efficacy and safety of NEPA, a fixed-dose combination of netupitant and palonosetron, for prevention of chemotherapy-induced nausea and vomiting following moderately emetogenic chemotherapy. Ann Oncol. 2014; 25:1328-1333.

36. Calcagnile S, Lanzarotti C, Gutacker M, Jakob-Rodamer V, Kammerer KP. Effect of food and age on the pharmacokinetics of NEPA (a fixed-dose combination of netupitant and palonosetron) in healthy volunteers. Eur J Cancer. 2013; 49:1327.

37. Lanzarotti C, Rossi G. Effect of netupitant, a highly selective $\mathrm{NK}$ (1) receptor antagonist, on the pharmacokinetics of midazolam, erythromycin, and dexamethasone. Support Care Cancer. 2013; 21:2783-2791.

38. Aapro MS, Walko CM. Aprepitant: drug-drug interactions in perspective. Ann Oncol. 2010; 21:2316-2323.

39. Colon-Gonzalez F, Kraft WK. Pharmacokinetic evaluation of fosaprepitant dimeglumine. Expert Opin Drug Metab Toxicol. 2010; 6:1277-1286.

40. Poma A CJ, Davis J KV, Martell RE HML. Phase 1 positron emission tomography (PET) study of the receptor occupancy of rolapitant, a novel NK-1 receptor antagonist. J Clin Oncol. 2014; 32.

41. Akynzeo Product Information Eisai Inc., Woodcliff Lakes, New Jersey. 2014.

42. Emend Package Insert Merck \& Co. Inc., Whitehouse Station, New Jersey. 2012.

43. Feyer P, Jordan K. Update and new trends in antiemetic therapy: the continuing need for novel therapies. Ann Oncol. $2011 ; 22: 30-38$.

44. Salsman JM, Grunberg SM, Beaumont JL, Rogers M, Paul D, Clayman ML, Cella D. Communicating about chemotherapyinduced nausea and vomiting: a comparison of patient and provider perspectives. J Natl Compr Canc Netw. 2012; 10:149-157.

45. Aapro MS, Schmoll HJ, Jahn F, Carides AD, Webb RT. Review of the efficacy of aprepitant for the prevention of chemotherapy-induced nausea and vomiting in a range of tumor types. Cancer Treat Rev. 2013; 39:113-117.

46. Kimura H, Yamamoto N, Shirai T, Nishida H, Hayashi K, Tanzawa Y, Takeuchi A, Igarashi K, Inatani H, Shimozaki S, Kato T, Aoki Y, Higuchi T. Efficacy of triplet regimen antiemetic therapy for chemotherapy-induced nausea and vomiting (CINV) in bone and soft tissue sarcoma patients receiving highly emetogenic chemotherapy, and an efficacy comparison of single-shot palonosetron and consecutiveday granisetron for CINV in a randomized, single-blinded crossover study. Cancer Med. 2015; 4:333-341.

47. Knobloch K, Yoon U, Vogt PM. Preferred reporting items for systematic reviews and meta-analyses (PRISMA) statement and publication bias. J Craniomaxillofac Surg. 2011; 39:91-92.

48. Moher D, Liberati A, Tetzlaff J, Altman DG. Preferred reporting items for systematic reviews and meta-analyses: the PRISMA statement. Int J Surg. 2010; 8:336-341.

49. Higgins J GS. Cochrane handbook for systematic reviews of interventions, v.5.1.0. Cochrane Collaboration. Updated March. 2011; www.cochrane-handbook.org.

50. Dias S WNJ, Sutton AJ AAE. NICE DSU technical support document 2: a generalised linear modelling framework for pairwise and network meta-analysis of randomized controlled trials. National Institute for Health and Care Excellence. Updated April 2014.

51. Brooks SP GA. General methods for monitoring convergence of iterative simulations. J Comput Graph Stat. 1998; 7:434-455.

52. Dias S, Welton NJ, Caldwell DM, Ades AE. Checking consistency in mixed treatment comparison meta-analysis. Stat Med 2010; 29:932-944. 